\title{
Credible Commitments and the International Criminal Court
}

The Harvard community has made this article openly available. Please share how this access benefits you. Your story matters.

\begin{tabular}{|ll|}
\hline Citation & $\begin{array}{l}\text { Simmons, Beth Ann, and Allison Danner. 2010. Credible } \\
\text { commitments and the International Criminal Court. International } \\
\text { Organization 64(2): 225-256. }\end{array}$ \\
\hline Published Version & doi:10.1017/S0020818310000044 \\
\hline Accessed & June 18, 2014 2:39:50 PM EDT \\
\hline Citable Link & http://nrs.harvard.edu/urn-3:HUL.InstRepos:9938752 \\
\hline Terms of Use & $\begin{array}{l}\text { This article was downloaded from Harvard University's DASH } \\
\text { repository, and is made available under the terms and conditions } \\
\text { applicable to Other Posted Material, as set forth at } \\
\text { http://nrs.harvard.edu/urn-3:HUL.InstRepos:dash.current.terms-of- }\end{array}$ \\
\hline \begin{tabular}{l} 
use\#LAA \\
\hline
\end{tabular}
\end{tabular}




\title{
Credible Commitments and the International Criminal Court
}

\author{
Beth A. Simmons and Allison Danner
}

\begin{abstract}
The creation of an International Criminal Court (ICC) to prosecute war crimes poses a real puzzle. Why was it created, and more importantly, why do states agree to join this institution? The ICC represents a serious intrusion into a traditional arena of state sovereignty: the right to administer justice to one's one nationals. Yet more than one hundred states have joined. Social scientists are hardly of one mind about this institution, arguing that it is (alternately) dangerous or irrelevant to achieving its main purposes: justice, peace, and stability. By contrast, we theorize that the ICC is a mechanism to assist states in self-binding, and draw on credible commitments theory to understand who commits to the ICC, and the early consequences of such commitments. This approach explains a counterintuitive finding: the states that are both the least and the most vulnerable to the possibility of an ICC case affecting their citizens have committed most readily to the ICC, while potentially vulnerable states with credible alternative means to hold leaders accountable do not. Similarly, ratification of the ICC is associated with tentative steps toward violence reduction and peace in those countries precisely least likely to be able to commit credibly to foreswear atrocities. These findings support the potential usefulness of the ICC as a mechanism for some governments to commit to ratchet down violence and get on the road to peaceful negotiations.
\end{abstract}

On 2 February 1999, Senegal became the first country to ratify the Rome Statute, the treaty creating the International Criminal Court (ICC or Court). Just eight years later-despite opposition from several major actors, including the United States,

We appreciate the comments we have received from Karen Alter, José Alvarez, David Carter, Jeff Checkel, Alex DeWaal, Jeffry Frieden, Hein Goemans, John Goldberg, Jack Goldsmith, Ryan Goodman, Andrew Guzman, Oona Hathaway, Laurence Helfer, Leslie Johns, Judith Kelley, Robert Keohane, Ernst Martens, Lisa Martin, Richard Price, David Singer, Anne-Marie Slaughter, Jack Snyder, Jessica Stanton, and Richard Steinberg. We also benefited from feedback from the International Law/International Relations Seminar at the Weatherhead Center for International Affairs, Harvard; International Security Workshop, Harvard; Political Economy Workshop, Harvard; the Vanderbilt International Law Roundtable; the International Law Workshop at the University of California Berkeley Law School, Simon Fraser University, McGill University, Princeton University, and the Hauser seminar at New York University Law School. We appreciate the excellent research assistance of Nicholas Fram, Allison Gruenwald, Marina Ivanova, Trung Nguyen, Alexander Noonan, Phillip Riblett, Matthew Roller, and Koppel Verma. We are grateful to members of Coalition for the International Criminal Court (CICC) who provided extensive data for this project. All errors of fact and judgment remain our own. Please note that the views expressed in this article do not necessarily represent the views of the Department of Justice or the United States. 
Russia, China, India, and, to a lesser extent, France-more than half of the sovereign states in the world embraced this independent international institution dedicated to prosecuting some of the most serious crimes known to humanity. International agreements defining the crimes of genocide and war crimes have existed for decades, but these prohibitions have been drastically underenforced. The development of the ICC represents a stunning change of course. Not only does the ICC promise more stringent enforcement of international crimes, it also takes away from sovereign states the discretion to decide when to initiate prosecutions - a right they have heretofore jealously guarded. Indeed, the decision by some national leaders to join the Court seems potentially to run against their self-interest, since it is widely assumed the ICC will focus on prosecutions of high-level figures in countries where mass atrocities occur.

Thus far, few social scientists have given this innovative institution close scrutiny. ${ }^{1}$ Those who have are often skeptical of its ability to deter international crimes and encourage peace and stability. Snyder and Vinjamuri argue that institutions bent on doling out universal justice are likely to cause more harm than good. ${ }^{2}$ Gilligan offers a formal model that shows this is not necessarily true, however, and shows that an institution such as the ICC might theoretically be able to deter some atrocities "on the margins." International lawyers are characteristically (though not uniformly) more optimistic. On the one hand, those such as Scheffer or Akhavan who have had close involvement with such tribunals are likely to attribute deterrent properties to them. ${ }^{4}$ By contrast, more removed legal scholars such as $\mathrm{Ku}$ and Nzelibe argue that international criminal tribunals are hardly likely to deter crimes by government opponents, whose calculations are overwhelmingly more likely to be influenced by harsh local sanctions than by lighter and less likely international ones. ${ }^{5}$ Optimists are likely to view international criminal tribunals as important influences on domestic values and cultural orientations toward violence ${ }^{6}$ pessimists (more plentiful among international relations scholars and increasingly vocal in the legal academy) ${ }^{7}$ remain largely unconvinced of such tribunals' transformative potential. ${ }^{8}$

The establishment of and adherence to the ICC is therefore a real conundrum. It was established by governments, but it is not clearly in any given government's interest. ${ }^{9}$ Some American observers believe the ICC is dangerous-both to U.S.

1. Exceptions include Fehl 2004, as well as the literature discussed below.

2. Snyder and Vinjamuri 2003/2004. For a contrary view, arguing that the ICC in fact sets parameters in which political settlements can take place, see Méndez 2001.

3. Gilligan 2006.

4. See Akhavan 2001; and Scheffer 2002.

5. $\mathrm{Ku}$ and Nzelibe 2006.

6. Kiss 2000 .

7. Goldsmith 2003.

8. Bloxham 2006.

9. For a "supply side" argument explaining why major powers such as the United Kingdom wanted to create an ICC in the 1990 s, see Katzenstein 2009. She argues that these powers wanted to avoid 
interests and to the cause of international peace and security more generally. Many more view the institution as irrelevant to the regions of the world it was intended to affect- those recently rent by violent civil conflict. The most puzzling aspect of the Court is why so many governments have accepted its jurisdiction over a range of atrocities. The delegation of real prosecutorial authority is truly anomalous and hard to explain if the ICC is merely a symbolic gesture toward "justice." We argue that the ICC can be understood through the lens of credible commitment theory, ${ }^{10}$ which provides a mechanism for understanding why states would agree to bind their own hands by forswearing certain violent options. This explanation also suggests that under certain circumstances an ICC commitment can contribute to an atmosphere conducive to conflict reduction and peaceful negotiation.

The insights of credible commitment theory explain an interesting but counterintuitive empirical regularity: all else equal, unaccountable autocracies that have endured recent internal conflict have decided to cooperate with the ICC in surprising numbers. In fact, other factors being equal, unaccountable autocracies are more likely to commit themselves to the Court than are democratic countries with a recent history of such conflicts. In contrast to theories that invest democracies in a blanket fashion with strong preferences for international law and cooperation, ${ }^{11}$ or theories that attribute international legal commitments to the diffusion of a world culture that currently promotes judicialization, ${ }^{12}$ this patterns suggests that some governments rationally use the ICC to tie their hands as they make tentative steps toward conflict resolution. This perspective suggests that the ICC may begin to have positive effects even before it prosecutes a single suspect.

This article is organized into four parts. The first provides a brief background to the ICC and discusses the treaty's institutional design. It sets up the argument by describing how the ICC is constituted to "tie the hands" of state parties when it comes to the tactics they use to gain military advantages. The second section presents credible commitments theory, discusses how it relates to civil settings and to the ICC, and generates a set of behavioral expectations consistent with the theory's claims. The third section discusses the data and methods we use to test our interpretation of the ICC as a rational tool governments use to tie their hands under certain circumstances. The fourth section tests the commitment patterns we anticipate if indeed the ICC is playing the commitment role we describe. The evidence fits a theory that the ICC is indeed useful for some governments credibly to tie their hands to foreswear certain modes of violent conflict. The conclusion contrasts this argument with alternative understandings of the Court as merely symbolic, or worse, detrimental to the cause of peace and stability. This case sheds

direct responsibility as "accountability police" and instead preferred to "outsource" this function to an independent court.

10. Fearon 1997.

11. See Dixon 1994; and Ho 2002.

12. On the idea of world culture as an explanation for much nation-state isomorphism, see Meyer et al. 1997 
new light on the crucial role that international law and institutions are increasingly playing in facilitating cooperation and conflict resolution even in highly conflictive settings.

\section{The International Criminal Court in Historical and Institutional Perspective}

\section{Background}

The twentieth century has been a remarkable period of international "judicialization." International courts and courtlike institutions have sprouted in surprising numbers to deal with specific functional problems, such as conflict over trade agreements or disagreements over the application of the Law of the Seas, and regional concerns such as individual human rights. The ICC is different from nearly all of these institutions. It is one of the few devoted to the enforcement of international criminal law, holding individuals accountable for violations with the potential to imprison for life persons convicted of such crimes. The ICC involves the potential transference to an international institution one of the most coveted aspects of state sovereignty: the right to administer justice within a state's territory.

The use of international criminal tribunals fell into desuetude during the Cold War, but the 1990s proved a propitious time to resurrect the idea. The end of the Cold War had reinvigorated the search for multilateral solutions to transnational problems, and establishing courts became a popular strategy. ${ }^{13}$ The global stability maintained for forty years by the United States and the Soviet Union had begun to crumble, leading to especially cruel civil wars in many regions of the world.

No one had an effective solution to quell these internal conflicts in the postCold War setting. But there was a growing sense, nurtured by nongovernmental human rights and humanitarian organizations, that impunity for crimes against humanity and genocide was hardly acceptable. In Yugoslavia and then Rwanda, a United Nations that could do little to stop the atrocities decided to establish ad hoc courts to punish the perpetrators. These tribunals formed a key precedent for the creation of the International Criminal Court. ${ }^{14}$ They illustrated that international criminal courts could function outside of the post-World War II setting and exposed the weaknesses of relying on the politicized UN Security Council for their creation.

Despite (or more likely because of) their weaknesses, the experience of these ad hoc arrangements energized human rights activists around the world to push

13. On the development of international law and judicial institutions over the past few decades, see Abbott and Snidal 2000; Abbott et al. 2000; and Keohane, Moravcsik, and Slaughter 2000.

14. This evolution is described further in Danner 2006. On the lessons of the ICTY for the ICC, see Tochilovsky 2003. 
for a permanent institution devoted to international criminal justice. ${ }^{15}$ The civil wars of the 1990s convinced activists and many government leaders that a standing Court with the ability to prosecute high officials — even national leaders-was a way to deter serious crimes and to contribute to peace. ${ }^{16}$ The international criminal regime was eventually designed such that this function would be carried out through national institutions where possible ${ }^{17}$ and the ICC where necessary.

\section{The ICC as an Institutional Innovation}

The primary innovation of the ICC is its institutional capacity to pre-commit stateswith few available loopholes - to cooperate with its criminal prosecutions for specific crimes. The Court has jurisdiction over all potential cases of genocide, crimes against humanity, and war crimes that occur after 1 July 2002 in the territory of a state that has ratified the treaty or that are committed by a national of such a state. ${ }^{18}$ Unlike the traditional model exemplified by the International Court of Justice, the treaty creating the ICC does not allow states to decide whether or not to accept the Court's jurisdiction on a case-by-case basis. ${ }^{19}$ Furthermore, unlike the original draft treaty for the Court, ${ }^{20}$ the Rome Statute invests a prosecutor with the ability to commence cases on her or his own initiative without relying solely on the referrals of states. ${ }^{21}$ The result is a Court much more independent of state control in the initiation of cases and far less protective of state sovereignty than was originally contemplated or has ever existed in modern history.

Other aspects of the Rome Statute also serve to tie officials' hands by increasing the likelihood of ICC prosecution for crimes within its jurisdiction. The Rome Statute does not allow states to make reservations to its provisions. ${ }^{22}$ Adherence is

15. On the course of negotiations and the influence of activists and NGOs, see Glasius 2006; Lee 1999; and Pace and Schense 2002.

16. See, for example, the Statement of Norway, 12 November 2001, available at 〈http://www. iccnow.org/documents/Norway6thComm12Nov01.pdf $>$. Accessed 8 January 2010.

17. The preamble to the ICC treaty highlights this point by "recalling that it is the duty of every State to exercise its criminal jurisdiction over those responsible for international crimes." Rome Statute of the International Criminal Court, 17 July 1998, UN Doc. A/CONF.183/9 (1998) [hereinafter Rome Statute].

18. Rome Statute, Article 12(2). A state may also accept the jurisdiction of the Court on an ad hoc basis with regard to that particular situation. Rome Statute, Article 12(3). In addition, the Court has jurisdiction over any case referred to it by the United Nations Security Council under its Chapter VII authority, whether or not the state where the alleged crimes occurred has ratified the treaty.

19. Lee 1999, 28

20. Draft Statute for the International Criminal Court, in Report of the International Law Commission on the Work of its Forty-Sixth Session, UN GAOR, 49th Sess., Supp. No. 10, at 43-45 (Article 23 and 25), UN Doc. A/49/10 (1994), reprinted in [1994] 2 Y.B. Int'1 L. Comm'n 46, UN Doc. A/CN.4/ Ser.A/1994/Add.1 (Part 2).

21. Danner 2003, 513-15. While frivolous or politically motivated prosecutions are a possibility (and one that has particularly concerned the United States), the Rome Statute has checks built into it to discourage a prosecutor from acting irresponsibly. These are described further in Danner 2003.

22. Rome Statute, Article 120. 
an all-or-nothing choice. ${ }^{23}$ In addition, the ICC does not recognize any of the immunities traditionally accorded to heads of state and other senior officials under international law. In fact the treaty overrides any immunities that states may grant to presidential, parliamentary, or legislative officials in their domestic systems. ${ }^{24}$ Moreover, the prosecutor has given every indication that he or she will in fact focus on high-level offenders ${ }^{25}$ - a threat each government has to weigh when deciding whether to ratify the statute.

Given these far-reaching provisions, the challenge for the drafters of the Rome Statute was how to encourage any state to join the International Criminal Court. The answer lies in the principle of complementarity: the ICC is meant to supplement—not supplant—domestic criminal law prosecutions. In the Rome Statute's complementarity regime, states with domestic jurisdiction over the crime must first have the option of investigating the case domestically before the ICC can adjudicate it. ${ }^{26}$ As the Court's first prosecutor has stated, "intervention by the ICC must be exceptional-it will only step in when states fail to genuinely act." 27

No state party's officials can be absolutely sure, however, that complementarity will protect them or their citizens from the Court's jurisdiction. The Court's judges may find a case "admissible" in the Court despite a domestic investigation or prosecution if the Court determines that "the state is unwilling or unable genuinely to carry out the investigation or prosecution." ${ }^{28}$ Sudan's desultory investigations and prosecutions of crimes committed in Darfur provide a clear example of the kind of behavior the admissibility provisions were designed to override. ${ }^{29}$

Finally, the structure of the Rome Statute does not allow governments to refer cases to the Court involving rebel groups without running the risk that the Court will also prosecute government officials. The drafters of the Rome Statute were careful to draft language into the treaty that allows states to refer "situations" to

23. The treaty does officially allow countries to decline to recognize the Court's jurisdiction for seven years after the state becomes a party to the treaty. Rome Statute, Article 124. Thus far, only France (who insisted on this provision in the treaty negotiations) and Colombia have entered the requisite declaration.

24. Rome Statute, Article 27.

25. According to the Prosecutor's Office, they "will initiate prosecutions of the leaders who bear most responsibility for the crimes." Quoted "Paper on Some Policy Issues Before the Prosecutor," Office of the Prosecutor, International Criminal Court, September 2003, 3. Available at $\langle$ http://www.icccpi.int/NR/rdonlyres/4780FCDE-7428-455A-BE01-E3BEE06920B4/248462/372619.pdf $\rangle$, accessed 8 January 2010.

26. See Rome Statute, Preamble (emphasizing that the ICC "shall be complementary to national criminal jurisdictions").

27. "A Global Web of Justice is Up and Running," International Herald Tribune (Internet ed.), 12 June 2006, available at $\langle\mathrm{http}: / / w w w . i h t . c o m / a r t i c l e s / 2006 / 06 / 11 / o p i n i o n / e d o c a m p o . p h p\rangle$. Accessed 8 January 2010.

28. Rome Statute, Article 17(1)(a).

29. See Office of the Prosecutor, International Criminal Court, "Third Report of the Prosecutor of the International Criminal Court, Mr. Luis Moreno Ocampo, to the UN Security Council Pursuant to UNSCR 1593 (2005),” 14 June 2006, available at 〈http://www.issafrica.org/AF/profiles/sudan/darfur/ iccunscjun05.pdf). Accessed 8 January 2010. 
the Court (covering the entire course of a conflict) instead of allowing them to limit their referrals to individual cases of wrongdoing. ${ }^{30}$ When Uganda referred crimes committed by the rebel group, the Lord's Resistance Army, to the ICC, the prosecutor was quick to highlight that he would investigate all crimes in Northern Uganda, implicitly including crimes allegedly committed by government forces. ${ }^{31}$ While governments may try and use the Court opportunistically, it was designed specifically to prevent them from insulating themselves from review.

Of course, none of these provisions guarantee that perpetrators of atrocities will be punished. There are many ways in which governments and other actors could try to subvert the work of the Court and loosen their self-chosen "constraints." As we have seen in the cases of the International Criminal Tribunal for Rwanda (ICTR) and International Criminal Tribunal for the Former Yugoslavia (ICTY), governments can interfere with prosecutions by strategically withholding evidence, interfering with investigations, and denying passports or visas to witnesses. ${ }^{32}$ As the examples of Serbia's Radovan Karadzic and Ratko Mladic demonstrate, alleged perpetrators can evade a tribunal for years, making it difficult for them to be brought to justice. It is also possible that a prosecutor could elect to forego prosecution. While prosecution is not a certainty, the existence of the Court significantly raises the expected costs of committing atrocities compared to the status quo of impunity. Any state that becomes a party to the ICC must allow for the very real possibility that if the government is responsible for atrocities, its most senior figures could be prosecuted either at home or in this Court-or pay a steep cost to avoid it. ${ }^{33}$

\section{The ICC and Credible Commitment Theory}

Why would governments ever agree to cooperate with an institution such as the ICC? There are two easy answers. The first is that governments anticipate they will never be in a situation in which their nationals will be subject to its jurisdiction. That might explain the enthusiasm of many of its more peaceful supporters, such as the Scandinavian countries, and this is indeed the calculation of many countries. The second easy answer is that governments expect to be able to use the ICC to legitimate the prosecution of their political opponents. While this explanation may be partially true, it cannot be the whole story. First, governments are just as vulnerable to the Court's jurisdiction as are rebels. Second, governments

30. Rome Statute, Article 14.

31. Office of the Prosecutor, International Criminal Court, "Statement by the Prosecutor Related to Crimes Committed in Barlonya Camp in Uganda” (23 February 2004).

32. Peskin 2008.

33. Serbia, for example, has suffered strong financial penalties for its failure to hand over individuals indicted by the ICTY. See "A Serbian Region Unravels with its Textile Industry," New York Times (Internet ed.), 29 January 2007. available at 〈http://www.nytimes.com/2007/01/29/world/europe/ 29serbia.html?_r=1\&oref=slogin $\rangle$. Accessed 8 January 2010. 
do not need the ICC threat to punish rebels; domestic processes are available for this purpose. The problem may be that domestic institutions may not be perceived as fair. If so, rebels are likely to resist both arrest and concessions and violence is likely to continue unabated. Thus, we advance a new interpretation of the ICC as a device to make governments' commitment to reduce civil violence credible by tying their own hands not only to prosecute fairly but potentially to be prosecuted as well.

\section{The Theory of Credible Commitments}

The central insight of credible commitment theory is that in many cases, actors have difficulty reaching cooperative solutions in their mutual relationships because they are unable to commit themselves credibly in advance to act in agreed or specified ways. ${ }^{34}$ There are a number of reasons one actor's promise to behave cooperatively might not be believed by others. One is the problem of cynical commitments: promises may be made by actors with no intention of living up to them. Another common problem arises from time-inconsistent preferences. An actor may sincerely want to promise to behave cooperatively in the present, but in the future it may be rational to renege opportunistically. Where threats, promises, or agreements cannot be enforced, actors find it difficult to convince one another they will behave in ways that may appear costly in the short term, even if to do so might produce greater benefits for the actor(s) concerned. ${ }^{35}$

What are the options for actors that want to enjoy the joint gains that may be possible from being able to commit to a particular course of action? Credible commitments theory emphasizes the need to raise the cost of defection ex post. Surrendering some sort of bond held by a third party in case of defection is one possibility (common in economic transactions). Another is to empower an independent third party to make and carry out policy decisions that effectively remove the decision from the credibility-challenged actor's authority (common in the implementation of monetary policy).

The problem is of course that sovereign states can hardly irrevocably tie their hands in the ways described here. More often the strategy is to make reneging on an agreement costly by raising the political costs of defection. Fearon has referred to "audience costs" as the generic set of political costs a government might face if it reneges on a commitment. ${ }^{36}$ Theoretically, audience costs can arise from the

34. For a discussion of commitment theory and domestic constitutions, see, for example, Elster 1979; Fearon 1997; and Holmes 1988. Credible commitment devices abound in international politics, from investment treaties with independent dispute-resolution mechanisms (Elkins, Guzman, and Simmons 2006) to exchange rate pegs (Bernhard, Broz, and Clark 2002, 706) to the international law doctrine of uti possidetis for territorial limitation (Ratner 2003).

35. Powerful actors can, paradoxically, be harmed by playing their dominant strategy. See $\mathrm{Maoz}$ and Felsenthal 1987.

36. Fearon 1997, 70 . 
negative reaction of any group in a position to inflict costs (such as withdrawal of support, aid, economic cooperation) on an actor who defects. Sovereign states may rationally try to raise their anticipated audience costs associated with defection if they want to make their commitments more credible in the first place. Credibility can be enhanced by deliberately making the noncooperative alternatives more costly.

Hands-tying in the way we have described is itself a costly option to pursue, which helps to reinforce the credibility of the commitment being made. Every effort by a state to tie hands practically by definition involves foregoing certain policy options. "Sovereignty costs" are the costs of giving up decision-making autonomy. The greater the sovereignty costs relative to the expected gain from making a credible commitment the less likely a government is to engage in hand tying. But where the potential gains of making a credible commitment are high, concerns about sovereignty costs will be overridden and a strategy of hand-tying is rational.

\section{Applying Hand-Tying Theory to the ICC}

Credible commitment theory can profitably be used to understand the stance of sovereign governments vis-à-vis the ICC. First, there is a good fit between the issues the ICC was meant to address and the theory of hand-tying. The problem of making credible commitments is rife in civil war settings, where governments can hardly be trusted to self-limit their resort to arms, if to do so would provide an important military advantage. Walter's research, for example, has found that one of the most significant hurdles in reaching a negotiated settlement to civil war is the problem of designing credible agreements on the terms of the peace agreement, "a task made difficult without credible outside assistance." 37

Similarly, credible commitments circumscribing war-fighting practices are difficult to make, especially in civil war settings. States' agents (as well as their military opponents) regularly resort to tactics that recklessly endanger civilians, wantonly mistreat prisoners, and violently persecute opposition groups, despite legal prohibitions to the contrary. ${ }^{38}$ The problem with most legal attempts to prevent such atrocities is that this violence may be "useful" in the short run; by demoralizing prisoners or the opposition's civilians it may be possible to coerce cooperation or reduce active resistance. ${ }^{39}$ From a government's long-term perspective, however, the commission of such atrocities can have disastrous consequences. Atrocities can fuel mistrust among victim groups and render a stable peace harder to negotiate. The perpetration of atrocities tends to make it harder

37. Walter 1999, 129. See also Posen's analysis of the security dilemma in civil war settings (Posen 1993). The unavailability of an enforceable contract is also central to Wagner's analysis of international wars. See Wagner 2000, 480.

38. Valentino, Huth, and Croco 2006.

39. Valentino, Huth, and Balch-Lindsay 2004, 376. They note that "intentional killing of civilians is often a calculated military strategy designed to combat powerful guerilla insurgencies." 
to form cooperative coalitions with an interest in dispute settlement. It may also imperil the government's survival. ${ }^{40}$ Governments may therefore have motives to end the cycle of civil violence, but they may have no way to make a promise to do so that any opposition group or even the general public will believe will last longer than the next security threat. The problem of time-inconsistent preferences is often quite real. ${ }^{41}$

The ICC offers a solution by raising the government's expected ex post costs of reneging. Joining the ICC greatly enhances the risk for states of future punishment of their senior leaders, at least by comparison to a regime of impunity. This exposure to prosecution by an independent international institution acts as an implicit promise by governments that they will foreswear particularly heinous military options, and it endows that promise with a credibility that such governments would otherwise lack.

What kinds of ex post costs might a government face for reneging? Legally, ratification of the ICC statute ${ }^{42}$ is a commitment made formally to the international community. As such it can trigger a potentially costly investigation, prosecution, and punishment of government officials or agents. But ratification also involves domestic audience costs by raising expectations among the general populace weary of violence that the government is committed to diffusing the conflict and seeking peaceful solutions. The frustration of these expectations by the commission of atrocities is likely to cost the government popular support. Thus we believe that the most important audience for this commitment in a society torn by civil war and at risk of mass atrocities is, in fact, domestic. The willingness of a government to subject itself to the risk of prosecution sends an important signal to a government's adversaries as well as the broader public that there are boundaries in quelling future threats beyond which the government will not go. The fact that a government cannot at low cost rescind or reverse this commitment reasonably enhances the perception that this government is interested in ratcheting down the violence and moving toward a peaceful solution to the conflict. Joining the ICC is therefore a form of self-binding commitment, in which states attempt to persuade other players-rebels, potentially supportive publics - that the government has voluntarily abandoned the option of engaging in unlimited violence, thus creating incentives for other actors to alter their behavior as well. ${ }^{43}$

All serious efforts to tie hands involve sovereignty costs, and this fact helps to anticipate which countries will support the Court and which will be resistant. Credible commitment theory expects states to ratify that will gain disproportionately

40. Carr $(2003,12)$ argues that "the nation or faction that resorts to warfare against civilians most quickly, most often, and most viciously is the nation or faction most likely to see its interests frustrated and, in many cases, its existence terminated."

41. Mégret $(2005, \mathrm{xi}, 32)$ theorizes commitment to the ICC as an "international anchoring of an inter-temporal commitment."

42. We refer to "ratification" to include both ratification and accession.

43. This is very similar to the definition of self-binding offered by Maoz and Felsenthal 1987, 187. 
from the act of hand-tying: those with a recent history of civil wars, but weak domestic institutions of accountability. ${ }^{44}$ Examples of such states in 2010 include Afghanistan, Peru, and the Democratic Republic of Congo. There is much less motive to delegate - and pay the sovereignty costs ${ }^{45}$ that ratifying the ICC implieswhere national mechanisms can credibly hold officials accountable. States that can credibly expose and prosecute misdeeds in their domestic institutions will try to do so without surrendering sovereignty to an external institution. Our approach suggests that states with a recent history of violence but relatively good domestic accountability mechanisms should tend to hold the ICC at arm's length. Countries making this calculation may include Bangladesh, India, and Indonesia who have recently experienced turbulent and sometimes violent internal conflicts. It could also potentially explain opposition of the United States, were the Court to focus its efforts on international rather than civil wars.

Credible commitment theory does not make strong predictions about the attitudes of states without civil wars in their recent past. These states are not likely to need the Court's war-crime-focused jurisdiction for credibility purposes. But a state with high accountability and low violence has a double protection against the jurisdiction of the Court: acts within the Court's jurisdiction are unlikely to be committed and if they are, the complementarity principle is almost certain to prevent the Court from launching an investigation. For this group of countries, cooperation with the ICC is simply not likely to be very costly. These governments can decide to support the Court—if at all—without concern for incursions into their sovereignty, since the likelihood of prosecution is anticipated to be effectively zero. They can make their decision to cooperate on other grounds, for example, on their assessment of the Court's ability to deter crimes elsewhere. These states may very well be sincere in their expectation that, in the words of the Norwegian delegation, the ICC will "provide the international community long term peace making dividends." ${ }^{46}$ Keep in mind, however, that they make this assessment knowing that the chances they will ever surrender a national to this institution are effectively zero.

The final category of states about which our theory does not make strong predictions is peaceful but unaccountable autocracies. There is no obvious reason for this group to worry about their credibility when it comes to the commission of ICC crimes, since they are unlikely to have committed any (which is not to say

44. On the substitution of international institutions for weak or nonexistent domestic institutions see Simmons and Martin 2002, 747-49

45. The term "sovereignty costs" is used here and elsewhere in the literature to refer to the costs that a state incurs by delegating a function ordinarily performed domestically to an international institution over which it has little, if any, control. See Abbott and Snidal 2000. Bradley and Kelley (2008, 19) argue that "sovereignty costs are higher for subjects that have traditionally been regulated by the state, such as criminal law and punishment."

46. Excerpts from the 6th Committee Discussion of Item 164: Establishment of the International Criminal Court, 56th Assembly of the United Nations, 12-13 November 2001. Available at 〈http:// coalitionfortheicc.org/documents/Norway6thComm12Nov01.pdf $>$. 
they have excellent human rights records), but moreover, they have no motive to tie their hands to reduce a cycle of domestic violence. The ICC may be viewed as largely irrelevant to them, and the decision to join will be driven by factors outside of our theory, many of which we test below.

A theory of hands tying leads us to a quite counterintuitive conclusion: the ICC will find its strongest support from a coalition of principled, highly accountable, nonviolent states, and violent states with weak domestic accountability mechanisms. The Scandinavians and certain African countries will both support the Court, the former in the possible belief that it will in fact lead to peace and security in troubled areas of the world; the latter because it solves a credibility deficit that makes it difficult to begin to ratchet down local violence. The Court will find its weakest support among countries engaged in recent violent conflicts, but with the institutional capacity credibly to hold those who commit atrocities accountable for their actions.

These predictions are quite distinct from other theoretical alternatives. Democratic theorists might expect all democracies to favor an effective ICC, by virtue of their affinity for justice, the rule of law, or bounded norms of democratic competition. ${ }^{47}$ Realists might expect all violent or powerful states to shun the ICC, on the assumption that states will have no interest in forswearing any instruments of coercion, regardless of their abhorrence. ${ }^{48}$ It is possible to design empirical tests to compare the explanatory power of these approaches, which we do in the remainder of the article.

\section{Data and Methods}

Evidence on governments' motive for joining the ICC is hard to come by. For the most part, the debates that led to the formation of the ICC were not made public, and those public statements that states have made give very little insight into their true motives for supporting and joining the Court. Many of the countries of central interest to our thesis-the authoritarian countries that have experienced recent civil war-ratified the Rome statutes with hardly a trace of legislative debate or justification. Qualitative research has turned up little other than bland statements about supporting the Court for purposes of ending impunity, restoring justice, enhancing stability, and establishing the rule of law. In diplomatic circles governments have simply not been specific about who they expect the Court to prosecute or exactly how or why they expect the Court to enhance peace and stability. We can draw few inferences of theoretical interest from government statements. For example, the delegate from Sierra Leone supported the Court, noting that "As a

47. See, for example, Dixon 1994, 15-18. By contrast, Goldsmith and Posner argue that cosmopolitan actions such as joining the ICC are not especially compatible with democratic governance. See Goldsmith and Posner 2005, 215-16

48. For a realist perspective, see Mearsheimer 2001. 
country emerging from conflict, and one that has chosen accountability and the restoration of the rule of law as the main vehicle to sustainable peace, we can attest first-hand to the crucial role of international criminal justice in ending conflict and restoring public confidence in the country and in its future." 49 Such a statement is consistent with many theories of how the Court might work, including the credible commitments approach we have developed here.

Similarly, the delegate from Lesotho declared during the debates that "respect for the Rule of Law cannot be achieved unless those who perpetrate evil and cruelty against other human beings are punished. For this reason it became imperative for us to create a fair and independent judicial body that would save future generations from the impending scourge of war." 50 Such statements reveal a conviction that an independent source of justice is necessary to peace, but allows for the possibility that such institutions can operate both domestically and internationally. (In addition to bolstering the independence of their judicial institutions over the last few years, Lesotho was an early ratifier of the Rome Statute.) Such generalities are echoed in the words of the delegate from Yugoslavia: "My country has supported the process leading to the establishment of a permanent International Criminal Court, convinced that such an independent and universally accepted international legal body will in the most effective manner contribut[e] to the ensuring of international peace and justice." 51 One can infer from this statement that the speaker acknowledges that domestic processes are often less than effective, and that the ICC can in these cases provide a more effective-because more crediblesubstitute. But in general, such statements provide few insights. Most countries who have supported the Court have made similar generalizations, but they reveal very little about the way supporters expect the Court actually to operate. Given the aridity of the formal record, we have decided to analyze actions rather than words. Thus we will look instead to how states have behaved toward the Court, and how its authority has cast an influence over the peace-making efforts of the major actors in civil conflicts.

\section{The Major Explanatory Variables: Civil War and Accountability}

Credible commitment theory suggests that states at risk for committing mass atrocities should be among the ICC's strongest supporters. Just who are these states? While the ICC is, as a legal matter, designed to address mass crimes that occur in

49. Statement by Ambassador Allieu I. Kanu, Head of Delegation of Sierra Leone, Fourth Session of the Assembly of States Parties.

50. Statement by His Excellency Mr. Percy Metsing Mangoaela, Permanent Representative of Lesotho to the United Nations, at the first meeting of the Assembly of States Parties, 9 September 2002.

51. Statement by H. E. Mr. Dejan Sahovic, Ambassador Extraordinary and Plenipotentiary Permanent Representative of the Federal Republic of Yugoslavia to the United Nations, Preparatory Commission for the International Criminal Court, 1 July 2002. 
international armed conflicts, in civil wars, and during times of "peace," the ICC is most likely to prosecute crimes associated with civil wars, ${ }^{52}$ which tend to be highly correlated with atrocities. ${ }^{53}$ We believe the states whose nationals are most at risk of prosecution if they choose to join the Court are those with recent domestic political violence. Thus we will test the hypothesis that states who have been involved in civil wars within the past five years are more likely to support the Court, conditional on these states' inability credibly to hold perpetrators accountable via domestic institutions. ${ }^{54}$ We code whether the country had experienced a civil war of any intensity during the post-Cold War years (since 1990) and before the Rome Statute was open for signature, with a minimum threshold of twentyfive battle deaths per year. ${ }^{55}$

Our next problem is to capture low domestic accountability. Note that prosecution is not the only way to hold leaders and their agents accountable. Information on government atrocities via a free press, competitive party systems through which policies can be discussed and criticized, periodic elections by which the public can assess the record of governance and decide whether to return a government to power, as well as politically independent courts and military tribunals are all mechanisms through which government agents can be held accountable for the methods they have selected to prosecute wars or maintain security. Without these kinds of institutions, atrocities are more difficult to bring to light, to assess, and to punish. A reasonable measure of accountability is therefore the existence of democratic institutions, which as a whole are more effective than autocratic ones for holding governments and their agents responsible for their actions. To measure democracy, we use the Freedom House measure of whether a country is "free," "partially free," or "not free." We consider the final category to constitute governments least able to commit credibly to lower levels of violence in civil conflicts. The Polity scale and the World Bank's "rule of law" scale are used to demonstrate the robustness of our findings.

52. The events most responsible for the renaissance of international criminal law-the crimes in Yugoslavia and the genocide in Rwanda-occurred in the context of civil wars; the ICC's actual first cases, those involving the Democratic Republic of Congo, Uganda, Central African Republic, and Sudan, also all involve civil wars; and much of the debate surrounding the ICC in fact centers on how it will affect civil conflicts. See, for example, Farer 2000. We agree with Ku and Nzelibe, 2006, 780, who argue that "for both legal and political reasons, ICT prosecutions will be directed almost exclusively at individuals engaged in civil conflict."

53. Valentino, Huth, and Balch-Lindsay 2004. Table A1 indicates that twenty-seven of thirty episodes of "mass killings" during wars between 1945 and 2000 occurred in civil wars. See also Easterly, Gatti, and Kurlat 2006; and Humphreys and Weinstein 2006.

54. This claim is consistent with the growing literature that attributes much greater domestic audience costs to democracies than to nondemocratic governments. See Schultz 2001, 34.

55. UCDP/PRIO Armed Conflict Dataset Codebook 3.10 (defining conflict intensity). (Version 3-2005), available at $\langle$ http://www.prio.no/CSCW/Datasets/Armed-Conflict/UCDP-PRIO/ $\rangle$. Accessed 8 January 2010. Appendices to this article are available at $\langle$ http://scholar.iq.harvard.edu/bsimmons/ publications/credible-commitments $\rangle$, accessed 2 February 2010. Appendix A lists the countries that have experienced civil war by this definition since 1990; Appendix B describes all variables used in this study. 


\section{Dependent Variable: ICC Commitment}

Credible commitment theory is predicated on the tying of one's hands through institutional arrangements that make it difficult or costly to reverse a promise. Often this is achieved through an irrevocable act of delegation to an authority over which the government has little control. ${ }^{56}$ In the case of the ICC, the crucial "tying of hands" takes place at ratification. Signature is not legally binding; it is only indicative of a state's willingness to participate in discussions relating to the formation of the Court and a commitment not to actively undermine the institution. ${ }^{57}$ We therefore consider ratification (or accession) to be the most significant indicator of hand-tying relevant to the commitment theory we have outlined here.

Our central expectations are:

Prediction 1: Low credibility states (nondemocracies, low rule-of-law states) that have recently experienced civil wars are likely to ratify the ICC.

Prediction 2: High credibility states (democracies, high rule-of-law states) that have recently experienced civil wars are not likely to ratify the ICC.

Prediction 3: High credibility states (democracies, high rule-of-law states) that have not recently experienced civil wars are likely to ratify the ICC.

\section{The Model: Event History Analysis}

Our central purpose is to infer the motives states may have for joining the ICC from their decisions whether to ratify the Rome Statute. We use event history analysis to analyze the extent to which both constant and time-varying factors influence the probability that a government will ratify the ICC statute in a given quarter, given that it has not yet done so. ${ }^{58}$ We have therefore arranged our data quarterly and delimited the relevant "spell" from the date from which the statute was open

56. The Rome Statute does allow states parties to withdraw from the Court if they provide one-year notice. Rome Statute, Article 127(1). The treaty does not, however, release states parties from any obligation to cooperate with the Court incurred while a member of the Court. Rome Statute, Article 127(2).

57. See Vienna Convention on the Law of Treaties, Article 18; and Swaine 2003, 2071.

58. Specifically we employ a Cox proportional hazard model, which estimates a "hazard rate" defined as:

$$
\mathrm{h}(\mathrm{t})=\frac{\text { probability of event between times } \mathrm{t} \text { and } \mathrm{t}+1}{(\mathrm{t}+1)(\text { probability of event after time } \mathrm{t})}
$$

where the "event" of interest is ratification. The hazard rate is then modeled as a function of the baseline hazard (ho) at time t-which is simply the hazard for an observation with all explanatory variables set to zero-as well as a number of explanatory variables, the estimates of which indicate proportional changes relative to this baseline hazard. The null hypothesis is that the proportionate hazard rate for any given explanatory variable of interest is 1 (it has no effect on the baseline hazard rate). 
for signature to the date of ratification. The results are reported as hazard ratios, which indicate the proportionate influence of a given factor on the decision to ratify. Numbers greater than one increase the hazard rate of ratification; less than one proportionately reduce the rate.

\section{Results: The Evidence of the ICC as a Mechanism for Credible Commitment}

\section{Ratification}

Ratification patterns of the Rome Statute provide strong support for the credible commitments theory (Table 1). Democracies with no recent history of civil war are quite likely to join the ICC. ${ }^{59}$ We have hypothesized that these countries constitute the Court's principled supporters who themselves are highly unlikely ever to find their nationals indicted. Both a dearth of conflict as well as credible domestic mechanisms for handling war crimes make this group willing to support the ICC secure in the knowledge that they will be highly unlikely ever to be subject to its jurisdiction. This group is more than two and a half times more likely (hazard ratio of 2.6, Model 1) to ratify the Rome Statute than are nondemocracies without recent civil war experience.

What is surprising from some perspectives, but expected by credible commitment theory, is that nondemocracies with recent civil war experience are highly likely to ratify the Statute quickly. According to Ratification Model 1, nondemocracies with civil wars are nearly three times more likely to ratify (hazard ratio of 2.84) than are nondemocracies without recent civil war experience. Of course, countries with practically no chance of their nationals appearing before the ICChighly accountable governments with no recent history of violent civil conflictare also very likely to ratify: more than twelve times more likely to do so than authoritarian regimes who similarly have no civil wars since 1990.

These findings show that, despite their completely different institutions and experiences, peaceful democracies and civil-strife ridden nondemocracies tend to display similar ratification propensities. By contrast, democracies with a recent history of civil war are far less likely to ratify the Rome Statute. A currently democratic country that experienced civil war between 1990 and 1997 is about 62 percent less likely to ratify the Rome Statute than is a nondemocracy without a recent past of civil violence (hazard ratio of 0.370 , Model 1 ). This finding supports credible commitment theory: the least credible but most violence-prone governments have joined the principled but nonvulnerable governments in ratifying the ICC treaty most readily.

59. Note that nondemocracies (low rule-of-law states) without recent civil war experience is the excluded category to which all three included democracy (rule of law)/conflict combinations are compared. 
Certain null results also support the theory of credible commitments. First, we found that these results hold up only for recent civil wars; civil wars in the more distant past do not seem to affect countries' calculations about whether or not to join the Court (not reported here). Since the Court's jurisdiction is prospective only, this result is unsurprising. The further in the past the civil war experience, the less necessary is the Court's prospective jurisdiction to the development of credibility. We also find the results do not hold up for ongoing civil wars, which is not what one would expect if states are simply using the ICC as a tool against immediate rebel opponents.

One of the primary alternatives to the ICC as a device for making credible commitments is the claim that governments join the Court not because they want to self-bind, but because they are trying to deter and to hold others responsible for their crimes. One version of this alternative points to the desire to hold future governments and their agents accountable for war crimes. Where governments face a high risk of regime change, they may have incentives to join the ICC to reduce impunity for future governments. ${ }^{60}$ There is little evidence for this idea. Unstable regimes and transitional regimes were no more likely to ratify the ICC statutes if they had a recent civil war than were more stable governments. ${ }^{61}$ Another alternative argument singles out the incentives governments may have for ratification if they are situated within especially violent regions or neighborhoods. Surrounded by the spillovers from other countries' civil conflicts, governments have incentives, this argument goes, to ratify the Court as a way to indict foreign citizens who commit atrocities in their territories. The large number of ratifications in central sub-Saharan Africa, for example, could be understood in these terms. There is some support for the dangerous neighborhood explanation, but it is not strong. Model 2, in Table 1, reports the strongest possible evidence we can produce for this argument. It suggests that when a country has had two or more civil wars on its borders within the past five years, that the government is about 9 percent more likely to ratify the ICC statutes than when it has had one or fewer $(p=.107)$. But this result is very sensitive to the number of civil wars on the border; it disappears when dividing the data at both one or three or more neighboring civil wars. Nor does it hold up when ongoing civil wars are used instead of those of the past five years. Even if concerns about importing others' atrocities is part of the answer, the size of the impact of neighboring civil wars is much smaller than the 2.4-fold increase associated with civil wars within nondemocratic countries.

These findings are highly robust to alternative explanations, as shown in Models 2 to 5 . One obvious alternative is that governments with large militaries might be hesitant to submit to the Court, for two reasons: large militaries provide more

60. For a similar argument with respect to the European Court for Human rights, see Moravcsik 2000.

61. Null results were found for the interaction of civil war and the standard deviation of regime type, as well as for the interaction of civil war and "transitional democracy" status (ever above 7 on the 10-point polity scale). Results available from authors. 
TABLE 1. Ratification of ICC Treaty, 1998-2007

\begin{tabular}{|c|c|c|c|c|c|c|c|}
\hline Explanatory variables & $\begin{array}{l}\text { Model 1 } \\
\text { (basic) }\end{array}$ & $\begin{array}{c}\text { Model } 2 \\
\text { (neighbors' } \\
\text { civil conflicts) }\end{array}$ & $\begin{array}{c}\text { Model } 3 \\
\text { (torture/amnesty } \\
\text { controls) }\end{array}$ & $\begin{array}{c}\text { Model } 4 \\
\text { (alliance, aid, } \\
\text { trade pressure) }\end{array}$ & $\begin{array}{c}\text { Model } 5 \\
\text { (socialization } \\
\text { controls) }\end{array}$ & $\begin{array}{c}\text { Model } 6 \\
\text { (basic, } \\
\text { conditioned on } \\
\text { polity score) }\end{array}$ & $\begin{array}{c}\text { Model } 7 \\
\text { (basic, } \\
\text { conditioned on } \\
\text { rule of law) }\end{array}$ \\
\hline $\begin{array}{l}\text { DEMOCRACIES }{ }^{1} \text { WITHOUT RECENT CIVIL } \\
\text { WARS }^{2}\end{array}$ & $\begin{aligned} & 12.64 * * * \\
\mathrm{p} & =0.000\end{aligned}$ & $\begin{aligned} 16.32 * * * \\
\mathrm{p}=0.000\end{aligned}$ & $\begin{aligned} 13.36 * * * \\
\mathrm{p}=0.003\end{aligned}$ & $\begin{aligned} & 10.69 * * * \\
& \mathrm{p}= 0.000\end{aligned}$ & $\begin{aligned} & 14.71 * * * \\
\mathrm{p} & =0.000\end{aligned}$ & $\begin{aligned} & 7.87 * * * \\
\mathrm{p}= & 0.000\end{aligned}$ & - \\
\hline DEMOCRACIES WITH RECENT CIVIL WARS & $\mathrm{p}=0.370^{* *}$ & $\begin{aligned} & 0.300 * * * \\
\mathrm{p}= & 0.003\end{aligned}$ & $\mathrm{p}=0.012$ & $\begin{array}{l}0.359 * * \\
\mathrm{p}= \\
0.021\end{array}$ & $\begin{array}{rl} & 0.305 * * * \\
\mathrm{p} & 0.010\end{array}$ & $\begin{array}{rl} & 0.338 * * * \\
\mathrm{p} & 0.003\end{array}$ & - \\
\hline $\begin{array}{l}\text { NONDEMOCRACIES WITH RECENT CIVIL } \\
\text { WARS }\end{array}$ & $\mathrm{p}=0.017$ & $\begin{aligned} & 3.56 * * * \\
\mathrm{p}= & 0.001\end{aligned}$ & $\begin{aligned} & 3.09 * * * \\
\mathrm{p}= & 0.007\end{aligned}$ & $\begin{aligned} & 3.13 * * * \\
\mathrm{p}= & 0.007\end{aligned}$ & $\begin{aligned} & 3.19 * * * \\
\mathrm{p}= & 0.009\end{aligned}$ & $\begin{aligned} & 2.49^{* *} \\
\mathrm{p}= & 0.005\end{aligned}$ & - \\
\hline $\begin{array}{l}\text { RULE-OF-LAW }{ }^{3} \text { STATES WITHOUT RECENT } \\
\text { CIVIL WAR }\end{array}$ & - & - & - & - & - & - & $\mathrm{p}=\begin{aligned} & 2.62^{*} \\
& 0.076\end{aligned}$ \\
\hline $\begin{array}{l}\text { RULE-OF-LAW STATES WITH RECENT CIVIL } \\
\text { WAR }\end{array}$ & - & - & - & - & - & - & 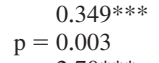 \\
\hline $\begin{array}{l}\text { LOW RULE-OF-LAW STATES WITH RECENT } \\
\text { CIVIL WARS }\end{array}$ & - & - & - & - & - & - & $\begin{aligned} & 2.70 * * * \\
\mathrm{p}= & 0.003\end{aligned}$ \\
\hline LOG MILITARY PERSONNEL & $\begin{aligned} & 0.720 * * * \\
\mathrm{p}= & 0.000\end{aligned}$ & $\begin{aligned} & 0.700^{* * *} \\
\mathrm{p}= & 0.000\end{aligned}$ & $\begin{aligned} & 0.740 * * * \\
\mathrm{p}= & 0.000\end{aligned}$ & $\begin{aligned} & 0.726^{* * * *} \\
\mathrm{p}= & 0.000\end{aligned}$ & $\begin{aligned} & 0.673 * * * \\
\mathrm{p}= & 0.000\end{aligned}$ & $\begin{aligned} & 0.617 * * * \\
\mathrm{p}= & 0.000\end{aligned}$ & $\mathrm{p}=0.000$ \\
\hline LOG PEACEKEEPERS & $\mathrm{p}=0.109$ & $\mathrm{p}=0.086$ & $\mathrm{p}=0.125$ & $\mathrm{p}=0.030$ & $\mathrm{p}=0.24$ & $\mathrm{p}=0.053$ & $\mathrm{p}=0.024$ \\
\hline REGIONAL RATIFICATION & $p=0.357$ & $p=0.369$ & $\begin{array}{c}1.01 \\
\mathrm{p}= \\
0.383\end{array}$ & $\mathrm{p}=\begin{array}{r}1.008 \\
0.510\end{array}$ & $\mathrm{p}=0.410$ & $\mathrm{p}=\begin{array}{r}0.999 \\
0.946\end{array}$ & $\mathrm{p}=\begin{array}{r}1.009 \\
0.416\end{array}$ \\
\hline HUMAN RIGHTS TREATIES & $\begin{aligned} & 1.38 * * * \\
\mathrm{p}= & 0.000\end{aligned}$ & $\begin{aligned} & 1.32 * * * \\
\mathrm{p}= & 0.000\end{aligned}$ & $\begin{aligned} & 1.44 * * * \\
\mathrm{p}= & 0.000\end{aligned}$ & $\begin{aligned} & 1.33 * * * \\
\mathrm{p}= & 0.010\end{aligned}$ & $\mathrm{p}=0.008$. & $\begin{aligned} & 1.32 * * * \\
\mathrm{p}= & 0.004\end{aligned}$ & $\mathrm{p}=0.001$ \\
\hline ONGOING EXTRATERRITORIAL CONFLICT & $\mathrm{p}=0.877$ & - & - & - & - & - & - \\
\hline CONSTITUTIONAL AMENDMENT REQUIRED & 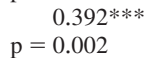 & $\begin{aligned} & 0.415^{* * * *} \\
\mathrm{p}= & 0.004\end{aligned}$ & $\begin{array}{l}0.421 * * * \\
\mathrm{p}= \\
0.003\end{array}$ & $\begin{aligned} & 0.406^{* * * *} \\
\mathrm{p}= & 0.002\end{aligned}$ & $\begin{aligned} & 0.432 * * * \\
\mathrm{p}= & 0.004\end{aligned}$ & $\begin{aligned} & 0.394 * * * \\
\mathrm{p}= & 0.003\end{aligned}$ & $\mathrm{p}=0.0312 * * \begin{array}{l}0.512 * \\
0.031\end{array}$ \\
\hline ICC ELECTED OFFICIALS & $\begin{aligned} & 2.74 * * * \\
\mathrm{p}= & 0.000\end{aligned}$ & $\begin{aligned} & 3.07 * * * \\
\mathrm{p}= & 0.000\end{aligned}$ & $\begin{aligned} & 3.04 * * * \\
\mathrm{p}= & 0.000\end{aligned}$ & $\begin{aligned} & 3.72 * * * \\
\mathrm{p}= & 0.000\end{aligned}$ & $\begin{aligned} & 2.83^{* * * *} \\
\mathrm{p}= & 0.000\end{aligned}$ & $\begin{aligned} & 2.97 * * * \\
\mathrm{p}= & 0.000\end{aligned}$ & $\begin{aligned} & 3.31 * * * \\
\mathrm{p}= & 0.000\end{aligned}$ \\
\hline ICC LEADERS & $\begin{aligned} & 2.37 * * * \\
\mathrm{p}= & 0.003\end{aligned}$ & $\begin{aligned} & 2.62 * * * \\
\mathrm{p}= & 0.001\end{aligned}$ & $\mathrm{p}=0.005$ & $\begin{aligned} & 1.27 \\
\mathrm{p}= & 0.521\end{aligned}$ & $\begin{aligned} & 2.77 * * * \\
\mathrm{p}= & 0.000\end{aligned}$ & $\begin{aligned} & 2.27 * * * \\
\mathrm{p}= & 0.008\end{aligned}$ & $\mathrm{p}=\begin{array}{l}2.53 * * * \\
0.002\end{array}$ \\
\hline BRITISH LEGAL HERITAGE (COMMON LAW) & $\begin{aligned} & 0.590^{* *} \\
\mathrm{p}= & 0.026\end{aligned}$ & $\mathrm{p}=0.005$. & $\begin{aligned} & 0.580^{* *} \\
\mathrm{p}= & 0.020\end{aligned}$ & $\mathrm{p}=0.068^{*}$ & $\mathrm{p}=0.003$ & 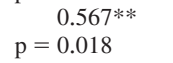 & $\mathrm{p}=0.027{ }^{0.57 *}$ \\
\hline
\end{tabular}


TWO OR MORE NEIGHBORS WITH CIVIL WARS,

PAST FIVE YEARS

WORST TORTURERS

AMNESTIES FOR ICC CRIMES

TRUTH COMMISSIONS

MILITARY ALLIANCE WITH U.S.

MLITARY ALLIANCE WITH EU

AID FROM U.S.

AID FROM EU

RADE WITH U.S. AS SHARE OF TOTAL

TRADE

TRADE WITH EU AS SHARE OF TOTAL

TRADE

LOG NONGOVERNMENTAL ORGANIZATIONS

LOG MULTILATERAL SUPPRESSION

TREATIES

Number of countries

Number of events

Number of observations

$\begin{array}{lr}- & \mathrm{p}= \\ - & 0.109 \\ - & - \\ - & - \\ - & - \\ - & - \\ - & - \\ - & - \\ - & - \\ - & - \\ - & -\end{array}$

1.09

-

1.40

$\mathrm{p}=0.517$

- 1.05

$\mathrm{p}=0.894$

.792

$\mathrm{p}=0.541$

- $\quad 1.08$

$-$

$2.79 * *$

$=0.001$

$=0.018$

$=0.078$

$\mathrm{p}=0.376$

1.005

$\mathrm{p}=0.139$

1.004

$\mathrm{p}=0.173$

-

$1.29 * *$

$\mathrm{p}=0.023$

1.05
$=0.894$

$189-18$

$\begin{array}{rr}189 & 186 \\ 100 & 96\end{array}$

-

$\mathrm{p}=0.894$

4992

$\begin{array}{rr}169 & 189 \\ 91 & 100\end{array}$

189
100
5189

4660

Notes: Table employs Cox proportionate hazard models with hazard ratios (p-values).

1. "Democracy" for Models 1 to 5 is coded as free or partially free on the Freedom House scale. As a robustness check, Model 6 codes a polity score above 0 as "democratic."

2. Measure used is civil war of any intensity during the 1990s prior to finalization of the ICC Treaty, namely 1990-97.

3. Rule-of-law states score above -1 and low rule-of-law states score below -1 on the World Bank rule-of-law scale.

* significant at .10; ** significant at .05; *** significant at .01 . 
targets for ICC investigations and they also constitute a powerful interest group to lobby against the institution. We find strong evidence consistent with these explanations. But we also find (with less certainty) that countries that supply many peacekeepers tended to ratify more readily. This likely reflects the commitment some governments have-for reasons we have not theorized here-to participate in multilateral projects supporting international peace and stability. For these states, the ICC is simply another tool in the promotion of global order. ${ }^{62}$ These two variables-size of military and contribution to peacekeeping-reveal opposite ratification tendencies for countries who use their militaries for primarily national versus primarily collective international purposes.

Alternative theoretical perspectives suggest the inclusion of other factors that could influence ratification, and we include appropriate indicators to see if they alter our main conclusions. Many studies have found that governments are significantly influenced by the ratifications of other countries in their region, whether because they have similar preferences or because they adopt regional practices in order to avoid criticism. ${ }^{63}$ If civil war and democracy cluster regionally, we may mistakenly have attributed rational commitment-making to a less rational process of regional emulation. In the case of the ICC, regional emulation is not a factor. While other human rights agreements may spark insincere emulation among peers, ratifying the ICC simply to follow regional norms is potentially risky precisely because it has teeth. This null result is highly consistent with the interpretation of the ICC we are advancing in this article, and a stark contrast with published findings for human rights treaties that lack external enforcement. ${ }^{64}$ Another possibility is that we have inadvertently confounded support for the ICC with support for human rights treaties in general. ${ }^{65}$ The predisposition to ratify human rights treaties is in fact highly correlated with ICC ratification, but this result does not disturb the main results about credible commitment-making.

It is also possible that governments ratify the ICC because they believe they will be able to control it to some extent. To test for this possibility, we have designated certain countries "leaders"- those with early involvement in the Court's design and with the resources to influence the direction of events. We defined "leaders" as the intersection of the "like-minded group" of states, which were committed to creating a robust and independent Court during the treaty negotiations, and Organization for Economic Cooperation and Development (OECD) membership (an organization of the wealthiest countries in the world). We also coded those countries whose nationals eventually did get elected to ICC positions, and we use this as a measure of anticipated influence over the institution. These indicators have moderate to strong effects in the expected direction (the eventual election of

62. See Neumayer 2009.

63. Simmons 2009, chap. 3.

64. Ibid.

65. Some social scientists have analyzed the ICC primarily as though it were a human rights institution. See Smith 2004. 
an official to the ICC nearly triples the propensity to ratify: hazard ratios range from 2.74 to 3.31 ), but they have practically no effect on our central finding on credible commitment-making. These findings further reinforce our view that, among democracies without recent civil wars (true for all countries categorized as "leaders"), the ICC is viewed as an institution that they are creating for others. The institution's most influential designers do not expect to be prosecuted there, but they correctly anticipate their officials will be elected to the Court, where presumably they may help protect their state's interests and reaffirm their state's values in the institution.

Another possibility is that ratification patterns may be driven by various domestic hurdles that make cooperation with the ICC institutionally difficult. ${ }^{66}$ To capture this possibility, we have collected data for each country on whether or not a constitutional amendment is required to cooperate with the Court. Unsurprisingly, countries with such constitutional requirements are indeed much less likely to ratify. Having such a requirement reduces the likelihood of ratifying by between 49 and 61 percent, but leaves the credible commitment story well intact.

Several of the robustness checks in Table 1 returned null results. We found no impact of ongoing extraterritorial conflict, which we included because we did not want our results to be driven by several countries' contemporaneous involvement in Iraq and Afghanistan. We included a series of other indicators of atrocities, such as widespread torture, amnesty for ICC crimes, and the use of truth commissions, but none of these affect the results (Model 3). We also considered the possibility that political relationships with members of the Europe Union (mostly in favor of the ICC) and the United States (vehemently opposed) might influence countries' ratification decisions (Model 4). There is evidence that military alliance with Europe increases the likelihood of ratifying, ${ }^{67}$ but contrary to expectations, so does foreign aid assistance from the United States. We found some evidence that the conclusion of so-called Article 98 Agreements with the United States-bilateral agreements not to cooperate with the Court in prosecuting one another's nationalshas positively influenced the decision of countries to ratify, although the direction of causation is unclear since the United States is more likely to want a mutual nonsurrender agreement with a party to the ICC, ceteris paribus, than a nonparty ${ }^{68}$ The concentrated presence of pro-ICC nongovernmental organizations (NGOs) as well as ICC-related conferences (not reported), may increase the chances of ratification, but participation in networks of multilateral treaties that include

66. For an example of the domestic constitutional hurdles that produced delay in ratification, see the case of Japan described by Meierhenrich and Ko 2009.

67. Military alliance with Europe is robust with the inclusion of Western and Eastern European dummy variables (either is statistically significant), so this is not simply a NATO effect.

68. Inclusion of an indicator for an Article 98 Agreement with the United States in the basic model approximately doubled the probability of ratifying the ICC $(p=.049)$; results available from authors on request, but had no effect on the central results. 
cooperative prosecution provisions apparently does not. ${ }^{69}$ While the evidence of socialization is mixed, it does not disturb our conclusion about the importance of credible commitment-making to explain ICC statute ratification.

Finally, we check for the robustness of our measure of "accountability." Our theoretical claim hinges on the idea that polities that are not equipped credibly to hold individuals_-including government officials and agents-responsible for war crimes are most likely to turn to the ICC to tie these officials' hands. We get similar results when we use the polity scale to measure accountability (diving that scale at zero); see Model 6. Moreover, weak "rule of law" countries should be especially willing in this perspective to engage the Court if the primary motive is to make a credible commitment to foreswear atrocities. Model 7 confirms this expectation quite strongly. The countries with the weakest rule of law (below -1 on the World Bank's scale; see Data Appendix) and a violent recent past were as or more likely to ratify the ICC statutes than high rule-of-law countries without recent civil wars. Countries with the internal institutions better able credibly to prosecute and with a recent history of civil violence were 65 percent less likely to ratify (hazard ratio of 0.349 ) than low rule-of-law countries without civil wars, and far less likely to ratify than countries with a weak rule of law and a recent civil war (hazard ratio of 2.7).

Overall, the evidence that states are motivated to ratify the Rome Statute in order to enhance their ability to make a credible commitment to refrain from atrocities in the future is consistently supported by the ratification evidence. Furthermore, these findings are consistent with results reported elsewhere that nondemocracies experiencing civil war in the recent past are also more likely actually to implement statutes to cooperate with the ICC as well. ${ }^{70}$ Many states seem to behave as though they have a motive to tie their hands through ICC jurisdiction. If this is in fact the case, we might also expect an ICC commitment to influence the prospects for peace-a proposition we explore in the following subsection.

\section{The Credibility of the Commitment: Hand-Tying and the Possibilities for Peace}

The fact that nondemocracies and low rule-of-law countries with recent civil wars tend to be among the most likely to ratify the Rome Statute provides evidence of behavior consistent with credible commitment theory. But how is this behavior interpreted by the various audiences these governments may be trying to influence? One answer is "suspiciously"-which would be consistent with the view that the Court is more about strategically targeting one's domestic enemies rather than self-binding. While governments make the formal legal commitment to an

69. All of these variables are defined in Appendix B. Available at 〈http://scholar.iq.harvard.edu/ bsimmons/publications/credible-commitments $\rangle$, accessed 2 February 2010.

70. Danner and Simmons 2006. 
international audience, the credible commitment theory we have developed relies principally on committing to a domestic audience, including one's political opponents, that the government is serious about de-escalating the conflict. But is this commitment understood as meaningful?

Obviously, credibility is impossible to observe. But we can assess the impact of ICC ratification on the presumed behavioral consequences of credible commitmentmaking. If the ICC really does help governments make credible commitments to their political opponents, ratification should, ceteris paribus, increase the likelihood of peace. The act of hands-tying should raise the ex post costs of committing atrocities by both government and opponents, providing space for a truce, trust building, and eventually a negotiated settlement. At least this is the hope of many who view the Court as an institution that can contribute to justice and stability.

Credible commitment theory predicts that the ICC can enhance movements toward peaceful settlement within those countries with credibility deficits. To test this idea, we begin with a simple model of civil war hiatus. We model the impact of the ICC on the propensity to terminate civil war hostilities, using the same event history strategy employed above. Table 2 reports the impact of ratification on episodes of civil war termination (defined as a one-year cessation in hostilities) between 1998 and 2007. Three different measures are used to capture accountability. (Unfortunately, colinearity problems in this subset of cases prevented use of the Freedom House measure.) Model 1 divides cases using the polity scale; Model 2 uses the World Bank's "rule of law" measure, and Model 3 taps accountability with a measure of political constraints on the executive power. Highly constrained executives are accountable to a legislature, opposition political parties, and the judiciary - all the more so when these actors have heterogeneous preferences and a will to influence and control the decisions of the executive. Credible commitment theory would suggest a greater impact of ICC ratification on peacemaking in countries where the executive is less constrained, and therefore institutionally less able to commit to a policy to which independent governing actors might hold him or her.

The results are largely consistent with our theoretical expectations. In all specifications, the governments with the weakest domestic accountability mechanisms that have ratified the Rome Statute are more likely to experience at least a lull in violent hostilities following ratification compared to the least accountable governments that have not ratified. Using both the polity scale and our measure of constraints on the executive, the effects of ratification on civil war termination are statistically significant. ${ }^{71}$ Model 1 estimates that the least democratic governments as measured by the polity scale are almost eight times more likely to terminate a

71. When the unit of analysis is conflict episode (allowing for multiple simultaneous conflicts and the reopening of conflicts after they have been terminated for a year) rule of law also supports our hypothesis. Counting conflicts in this way, ratification among the lowest rule-of-law countries increased the probability of civil conflict termination five fold, but had no effect in cases scoring above -1 on the rule-of-law scale. Results available from author. 
violent conflict if they have ratified the ICC statutes (hazard ratio of 7.84) than if they have not. According to Model 3, among the least constrained executives ratification is associated with more than a nine-and-a-half-fold increase in the probability of war termination. Finally, just as the theory anticipates, ratification has little independent effect on peace where domestic institutions arguably provide reasonable assurances of government accountability.

These results are suggestive that ratification signals a domestic adversary that a government wants to ratchet down the level of violence, and is willing to tie its hands in that regard. We do not claim, of course, that the ICC is solely or even primarily responsible for hastening a cessation of civil war hostilities in most cases. Unsurprisingly, conflict intensity decreases the likelihood of cessation, as do in this case domestic efforts at "reconciliation" such as truth commissions, at least in Model 1. Other controls - the country's military power, whether the government was headed by a military officer, the radius of the conflict, various measures of external aid-had no discernable effect. Table 2 suggests we can be cautiously confident that governments with low levels of "inherent" credibility that have ratified the ICC are more likely to experience at least a year's gap in their civil war violence than those that have not.

We also test whether ICC ratification leads to efforts to reach a more durable peace arrangement in civil war situations. And we can bolster our ability to draw inferences about ICC ratification by using a two-stage model that endogenizes the decision to ratify itself. That is, we can ask what is the effect of ratifying the Rome Statute on the probability of reaching a peace accord, controlling for the factors associated with ratifying the ICC in the first place? Using an instrumental probit model (described below), inferences about the value of the costly commitment per se can be isolated in a more precise fashion.

In order to identify such a model, we use instruments that predict ratification, but that in themselves do not increase the likelihood of reaching a civil peace accord. The previous tests revealed the importance of constitutional barriers to ratification (the need for amendment), a civil law legal tradition, and the signing of international human rights treaties as strong predictors of ICC ratification. Yet there is no strong theoretical reason to expect these conditions to lead to peace accords in a domestic civil war. ${ }^{72}$ We therefore use these as instruments in a twostage instrumental variable probit model (controlling for time dependence with a counting vector and cubic splines for both peace accords and ratification in the second stage equation). As in Table 2, for clarity and comparison, we have divided

72. Nor are these measures good empirical predictors of the conclusion of peace agreements. The results of a probit model with PEACE AGREEMENT as a dependent variable (pseudo $\mathrm{R}^{2}=0.0091$ ) and these instruments as explanatory variables indicate they are not likely correlated with the outcome. For the variable CONSTITUTIONAL AMENDMENT, the coefficient is -0.249 , with standard error of 0.386 and $\mathrm{P}>|\mathrm{z}|$ of 0.519 ; for RATIFICATION, the coefficient is 0.045 , with standard error of 0.081 and $\mathrm{P}>|\mathrm{z}|$ of 0.578 ; for BRITISH LEGAL HERITAGE (COMMON LAW), the coefficient is 0.150 , with standard error of 0.209 and P > $|\mathrm{z}|$ of 0.472 ; and for LOG OF MILITARY PERSONNEL, the coefficient is 0.013, with standard error of 0.043 and $\mathrm{P}>|\mathrm{z}|$ of 0.762 . 
TABLE 2. Effect of ICC ratification on civil war termination

\begin{tabular}{|c|c|c|c|c|c|c|}
\hline \multirow[b]{2}{*}{ Explanatory variables } & \multicolumn{2}{|c|}{ Model 1} & \multicolumn{2}{|c|}{ Model 2} & \multicolumn{2}{|c|}{ Model 3} \\
\hline & Polity $>0$ & Polity $<1$ & $\begin{array}{c}\text { WB rule } \\
\text { of law }>-1\end{array}$ & $\begin{array}{c}\text { WB rule } \\
\text { of law }<-1\end{array}$ & $\begin{array}{c}\text { Political } \\
\text { constraints }>0\end{array}$ & $\begin{array}{c}\text { Political } \\
\text { constraints }=0\end{array}$ \\
\hline \multirow[t]{2}{*}{ RATIFICATION } & 1.000 & $7.84 * *$ & 1.00 & 1.96 & 1.00 & $9.51 *$ \\
\hline & $\mathrm{p}=0.853$ & $\mathrm{p}=0.047$ & $\mathrm{p}=0.998$ & $\mathrm{p}=0.344$ & $\mathrm{p}=0.995$ & $\mathrm{p}=0.083$ \\
\hline \multirow[t]{2}{*}{ CONFLICT INTENSITY } & 1.05 & $0.134 * * *$ & 0.538 & $0.262 * *$ & 0.631 & $0.143 * * *$ \\
\hline & $\mathrm{p}=0.909$ & $\mathrm{p}=0.000$ & $\mathrm{p}=0.120$ & $\mathrm{p}=0.012$ & $\mathrm{p}=0.195$ & $\mathrm{p}=0.005$ \\
\hline \multirow[t]{2}{*}{ TRUTH COMMISSION } & 0.651 & $0.204 * *$ & $0.278 * *$ & 0.762 & 0.633 & $0.211 * *$ \\
\hline & $\mathrm{p}=0.366$ & $\mathrm{p}=0.043$ & $\mathrm{p}=0.041$ & $\mathrm{p}=0.724$ & $\mathrm{p}=0.335$ & $\mathrm{p}=0.024$ \\
\hline \multirow[t]{2}{*}{ COUNTRY'S MILITARY POWER } & 0.005 & 0.000 & 36.15 & 0.000 & 0.000 & 0.000 \\
\hline & $\mathrm{p}=0.745$ & $\mathrm{p}=0.125$ & $\mathrm{p}=0.856$ & $\mathrm{p}=0.281$ & $\mathrm{p}=0.421$ & $\mathrm{p}=0.871$ \\
\hline \multirow[t]{2}{*}{ LOG OF MILITARY PERSONNEL } & 0.862 & 0.513 & 0.770 & 1.31 & 0.974 & 0.647 \\
\hline & $\mathrm{p}=0.401$ & $\mathrm{p}=0.246$ & $\mathrm{p}=0.110$ & $\mathrm{p}=0.601$ & $\mathrm{p}=0.873$ & $\mathrm{p}=0.518$ \\
\hline \multirow[t]{2}{*}{ EXECUTIVE A MILITARY OFFICER } & $0.062 *$ & 1.07 & 1.57 & 1.07 & 0.613 & 1.30 \\
\hline & $\mathrm{p}=0.078$ & $\mathrm{p}=0.918$ & $\mathrm{p}=0.535$ & $\mathrm{p}=0.906$ & $\mathrm{p}=0.523$ & $\mathrm{p}=0.734$ \\
\hline \multirow[t]{2}{*}{ TOTAL AID/GDP } & $1.07 * *$ & 0.996 & 1.02 & 0.996 & 1.01 & 1.00 \\
\hline & $\mathrm{p}=0.021$ & $\mathrm{p}=0.912$ & $\mathrm{p}=0.572$ & $\mathrm{p}=0.854$ & $\mathrm{p}=0.626$ & $\mathrm{p}=0.938$ \\
\hline MILITARY ALLIANCE WITH THE & 0.784 & 0.468 & 1.80 & 0.820 & 1.02 & - \\
\hline U.S. OR EUROPEAN COUNTRY & $\mathrm{p}=0.799$ & $\mathrm{p}=0.644$ & $\mathrm{p}=0.582$ & $\mathrm{p}=0.872$ & $\mathrm{p}=0.974$ & \\
\hline Number of countries (or episodes) & 24 & 28 & 25 & 23 & 31 & 19 \\
\hline Number of events & 18 & 16 & 19 & 15 & 23 & 11 \\
\hline Number of observations & 412 & 376 & 423 & 365 & 523 & 265 \\
\hline
\end{tabular}

Notes: Table employs Cox proportionate hazard model. Dependent variable is probability of civil war termination, $1998-2007$ (first termination episode only). It was not possible to analyze the effect of ratification for countries scoring 0 on the Freedom House scale, due to colinearity with ratification for this group. WB = World Bank.* significant at .10; ** significant at $.05 ; * * *$ significant at .01 . 
the sample of civil war countries into democracies versus nondemocracies, high versus low rule-of-law states and constrained versus unconstrained executives. The results are reported in Table 3.

The results of these tests are unambiguous and remarkably consistent with credible commitment theory. In every model, ICC ratification among the least accountable governments has a significant positive effect on the probability that a peace agreement will be reached in a country plagued by a recent or ongoing civil war. However, ratifying the ICC does not clearly have an independent effect on the prospects for peace in high rule-of-law states or states in which the chief executive is highly constrained by domestic governing institutions. There does seem to be a strong positive effect in countries that are democratic (rated as "free" by Freedom House), but it is telling that the positive coefficient is much smaller than that estimated for countries that are "not free." The hands-tying function of the ICC makes a difference primarily in those countries least able to make credible commitments on their own. As expected, ratification does not add much on the margin to the peacemaking process in countries that already have reasonably strong accountability mechanisms in place. Moreover, exactly as we should expect if ratification benefits flow from hands-tying, there is not much peace-making advantage to signature alone. Every model controls for the impact of having signed the ICC statutes, indicating an "intent" to cooperate with that institution. Expressing only an "intent" to cooperate with the ICC does not contribute at all to the probability that a low rule-of-law state will enter into a peace agreement with its civil adversaries. This is strong evidence indeed of the usefulness of using legally binding arrangements to achieve outcomes that both parties-governments and domestic adversaries-may wish to achieve.

Ratification of the ICC positively impacts the probability of peace accords controlling for an array of other factors. One of these is whether the executive is a military officer or civilian. Military leaders are positively associated with peace accords only in one specification (in low rule-of-law cases), but never in democratic, high rule-of-law polities and constrained governments (where they are exceedingly rare). What does seem to matter is the intensity of the conflict itself. Where the accountability of the government was highest, higher intensity conflicts were always associated with a greater likelihood that a peace accord would be reached - a result that does not hold for the least accountable governments. Apparently, the more accountable the government, the greater the desire and presumably the more intense the pressure to end high-intensity violent civil conflict. Foreign aid seems to be associated with a reduction in the probability of reaching a peace settlement, especially when less accountable governments are involved. Of course, this analysis does not include selection effects-donors may choose to provide aid in precisely the most difficultto-solve cases; examples as diverse as Israel and Somalia illustrate the point.

Finally, we might be wrong in assuming that nonaccountable governments cannot make credible commitments domestically to refrain from atrocities. Perhaps less accountable governments can pass domestic rules that their opponents interpret as credible hand-tying. We test for this possibility by exploiting data we have coded 
TABLE 3. Effect of ICC ratification on peace agreements 1998-2007

\begin{tabular}{|c|c|c|c|c|c|c|}
\hline \multirow[b]{2}{*}{ Explanatory variables } & \multicolumn{2}{|c|}{ Model 1} & \multicolumn{2}{|c|}{ Model 2} & \multicolumn{2}{|c|}{ Model 3} \\
\hline & $\begin{array}{l}\text { Democracies } \\
\quad(F H>0)\end{array}$ & $\begin{array}{l}\text { Nondemocracies } \\
\quad(F H=0)\end{array}$ & $\begin{array}{l}\text { High rule-of- } \\
\text { law states } \\
(W B>-1)\end{array}$ & $\begin{array}{l}\text { Low rule-of- } \\
\text { law states } \\
(W B<-1)\end{array}$ & $\begin{array}{l}\text { More constrained executives } \\
(\text { political constraints }>0)\end{array}$ & $\begin{array}{l}\text { Less constrained executives } \\
(\text { political constraints }=0)\end{array}$ \\
\hline \multirow[t]{2}{*}{ RATIFICATION } & $3.445^{*}$ & $5.2 * * *$ & 3.304 & $3.89 * * *$ & 2.426 & $4.31 * * *$ \\
\hline & $\mathrm{p}=0.051$ & $\mathrm{p}=0.000$ & $\mathrm{p}=0.299$ & $\mathrm{p}=0.000$ & $\mathrm{p}=0.736$ & $\mathrm{p}=0.003$ \\
\hline \multirow[t]{2}{*}{ SIGNATURE } & -0.293 & -0.0995 & -0.201 & -0.198 & 0.064 & -0.367 \\
\hline & $\mathrm{p}=0.298$ & $\mathrm{p}=0.528$ & $\mathrm{p}=0.662$ & $\mathrm{p}=0.411$ & $\mathrm{p}=0.94$ & $\mathrm{p}=0.469$ \\
\hline \multirow[t]{2}{*}{ INTENSITY OF CONFLICT } & $0.237^{*}$ & 0.015 & $0.293 *$ & 0.041 & $0.404 * * *$ & -0.088 \\
\hline & $\mathrm{p}=0.061$ & $\mathrm{p}=0.927$ & $\mathrm{p}=0.073$ & $\mathrm{p}=0.801$ & $\mathrm{p}=0.006$ & $\mathrm{p}=0.661$ \\
\hline \multirow[t]{2}{*}{ SIZE OF STATE'S MILITARY (PERSONNEL) } & 0.041 & 0.034 & 0.011 & -0.002 & 0.002 & 0.007 \\
\hline & $\mathrm{p}=0.368$ & $\mathrm{p}=0.643$ & $\mathrm{p}=0.859$ & $\mathrm{p}=0.97$ & $\mathrm{p}=0.983$ & $\mathrm{p}=0.944$ \\
\hline \multirow[t]{2}{*}{ EXECUTIVE A MILITARY OFFICER } & 0.194 & -0.061 & 0.122 & $0.262 *$ & -0.226 & -0.041 \\
\hline & $\mathrm{p}=0.377$ & $\mathrm{p}=0.699$ & $\mathrm{p}=0.688$ & $\mathrm{p}=0.074$ & $\mathrm{p}=0.588$ & $\mathrm{p}=0.800$ \\
\hline \multirow[t]{2}{*}{ TOTAL AID/GDP } & -0.006 & $-0.050 * * *$ & -0.018 & $-0.026^{* * *}$ & -0.023 & $-0.025^{* * *}$ \\
\hline & $\mathrm{p}=0.481$ & $\mathrm{p}=0.001$ & $\mathrm{p}=0.223$ & $\mathrm{p}=0.001$ & $\mathrm{p}=0.411$ & $\mathrm{p}=0.006$ \\
\hline \multirow[t]{2}{*}{ CRIMINAL STATUTES } & -0.106 & -0.188 & -0.013 & $-0.5 * *$ & 0.03 & -0.116 \\
\hline & $\mathrm{p}=0.655$ & $\mathrm{p}=0.359$ & $\mathrm{p}=0.966$ & $\mathrm{p}=0.018$ & $\mathrm{p}=0.956$ & $\mathrm{p}=0.557$ \\
\hline \multirow[t]{2}{*}{ Constant } & -2.25 *** & $-2.69 * * *$ & $-2.34 * * *$ & $-2.18 * * *$ & -1.83 & $-2.34 * * *$ \\
\hline & $\mathrm{p}=0.000$ & $\mathrm{p}=0.000$ & $\mathrm{p}=0.000$ & $\mathrm{p}=0.000$ & $\mathrm{p}=0.102$ & $\mathrm{p}=0.000$ \\
\hline Number of observations & 1488 & 881 & 1662 & 704 & 1587 & 782 \\
\hline
\end{tabular}

Notes: Instrumental variable probit estimation, with ICC RATIFICATION instrumented. Robust standard errors (clustered on country). Instrumented $=$ ICC ratification. Instruments $=$ whether a constitutional amendment is required for ratification, number of human rights treaties ratified, British common law system, counting vectors and cubic splines for ratification and peace agreements, plus all variables reported above. WB $=$ World Bank. * significant at .10; ** significant at .05; *** significant at .01. 
on whether or not governments have changed their domestic criminal statutesunilaterally, with or without ratification of the ICC - by making ICC crimes a part of the domestic criminal code. ${ }^{73}$ If nondemocratic countries are in fact able to convince their domestic opponents that they will refrain from atrocities using only domestic sources of enforcement, we should find a positive impact to such changes in domestic law analogous to the ICC commitment itself.

As it turns out, there is no evidentiary basis for revising our assumption about nonaccountable governments. Quite the contrary: changing the domestic criminal statutes to match the obligations contained in the ICC (which we code as having imported "crimes against humanity" as a crime prosecutable in domestic courts) has, if anything, a negative impact on the prospects for peace accords, especially in less accountable countries. Outlawing crimes against humanity in domestic law is hardly a useful option in these cases. ${ }^{74}$

\section{Conclusion}

This article addresses a puzzle in international relations of the first order-namely, why states would voluntarily delegate an essential sovereign function to an international institution over which they have little political control? A surprising number of adherents have had serious problems with violent internal conflict, yet are unable to deal with the worst atrocities in a way that inspires trust from domestic groups or the international community. One way to think about the delegation issue is through the lens of theories of credible commitment-making. This approach predicts that states that are at risk for committing the kinds of atrocities governed by the Court but that lack a dependable domestic mechanism for holding government agents accountable are likely to be among the Court's earliest and most avid subscribers.

The evidence for this interpretation of delegation received strong support in our empirical analysis. Despite exhaustive robustness tests taking alternative measures and explanations into account, we found fairly consistently that the least accountable governments - the least democratic, with the weakest reputations for respecting the rule of law, the least politically constrained-with a recent past of civil violence were at the highest "risk" of ratifying the Rome Statute. Along with countries whose nationals were least likely ever to be vulnerable to the Court's jurisdiction (and for whom sovereignty costs were therefore likely to be very low), the least credible but most vulnerable governments were found to be among the

73. For this criminal legislation, we coded whether the country's penal code contained a provision penalizing "crimes against humanity." Since countries that had not ratified the Rome Statute might also decide to change their criminal code (perhaps to preempt ICC jurisdiction), and because states parties are not legally obligated to do so, we model the decision of any state (not just ratifiers) to change its criminal code in this way.

74. On the problems associated with flawed implementation of ICC criminal standards in domestic law, see Bacio Terracino 2007. 
earliest ratifiers. The characteristics associated with a need to make a credible commitment to forswear atrocity as an instrument of war-fighting were consistently associated with high rates of cooperation with the ICC.

One innovation of this research is that it has examined not only the commitment decision, but the observable implications of this decision for incipient processes of peacemaking. This is a crucial step, because the Court has been derided repeatedly — and with little systematic evidence - as either disruptive or irrelevant to its purported raison d'être: support of international peace and stability. We have found evidence that for states unable to make credible promises to scale down the violence, ICC ratification is associated with tentative steps toward peacemaking. Our findings in all three cases_-explaining ratification, civil war hiatus/termination, and peace accords - converge on a possible motive for delegation: the strong desire of some states to establish their credibility with a domestic audience to fight fair.

This article also carefully considered a number of plausible alternative explanations. Some were clearly found wanting. The idea that ratification is purely symbolic does not square with the facts. We have argued that this is an institution with the power to put real people in prison for most of their lives. Symbolism alone does not explain this decision, especially when one of the world's major powers, the United States, offers a powerful alternative symbol to justify nonratification: state sovereignty over prosecution. The ICC is not the obvious place to engage in purely symbolic gestures; governments have plenty of opportunities to make symbolic gestures in international law by ratifying the numerous treaties devoid of external enforcement provisions. Indeed, the absence of any regional emulation in making the ratification decision stands in stark contrast to the empirical findings relating to a broad range of human rights treaties that do lack external enforcement provisions. Nor can states' cooperation with the ICC be understood as simply trying to hold others accountable. We have explained how the prosecutor is authorized to investigate situations, not particular individuals; states therefore cannot escape the risk that their agents will come under scrutiny and could be prosecuted. And our null finding with respect to ongoing civil wars does not support an immediate strategy of using the Court to prosecute rebels. The desire to prosecute dangerous neighbors is a possibility, but we found this effect to be small compared to a civil war in a state's recent past. Even the evidence that ratification is associated with conditions likely to bind a future government was weak. It is hard to escape the conclusion that self-binding plays a significant role in understanding why states have become a party to the ICC.

It is important to emphasize what this research does not show. We have not shown that the ICC will in fact deter all or even most atrocities in the future. ${ }^{75} \mathrm{We}$ cannot claim - as no one can at this point in history - that the ICC will contribute to permanent peace among factions that have been locked in civil war for years.

75. Existing research emphasizes the idiosyncratic nature of specific cases rather than general trends that might reveal how the Court can be expected to operate. See, for example, Alexander 2008/2009. 
Nor do we claim credible commitment-making is the only motive at work. Ratification was shown to be influenced by the nature of domestic legal systems and to be significantly less likely in states with a large military. There is ample room to theorize the perceived appropriateness of joining the ICC from the perspective of agents operating in common law versus civil law settings,${ }^{76}$ constitutional barriers, and the importance of the military as a domestic interest group as additional explanations for engagement (or not) with the ICC. Yet throughout, we found convincing evidence that governments least able credibly to prosecute war-related atrocities were among those most likely to embrace the new international criminal law regime, as well as behavioral evidence that this commitment meant something to domestic adversaries. This finding is consistent with a new stream of legal research that explores the significance of international law and institutions to bind governments' hands in ways that allow them to achieve results that would not be possible in the absence of international legal institutions. ${ }^{77}$

Finally, we do not claim that the Rome Statute's most significant legacy will necessarily ultimately lie in the credibility mechanism we have described. ${ }^{78}$ It is important to remember that this mechanism applies to only a small (but important) subset of states. Whether in the long run the combined effects of external hands-tying and the domestic changes the Court is precipitating will in fact reduce the commission of mass crimes and support peace will ultimately be the best test of the contribution of the ICC to justice and stability.

\section{References}

Abbott, Kenneth W., Robert O. Keohane, Andrew Moravcsik, Anne-Marie Slaughter, and Duncan Snidal. 2000. The Concept of Legalization. International Organization 54 (3):401-19.

Abbott, Kenneth W., and Duncan Snidal. 2000. Hard and Soft Law in International Governance. International Organization 54 (3):421-56.

Akhavan, Payam. 2001. Beyond Impunity: Can International Criminal Justice Prevent Future Atrocities? American Journal of International Law 95 (1):7-31.

Alexander, James F. 2008/09. The International Criminal Court and the Prevention of Atrocities: Predicting the Court's Impact. Villanova Law Review 54:1-55.

Bacio Terracino, Julio. 2007. National Implementation of ICC Crimes: Impact on National Jurisdictions and the ICC. Journal of International Criminal Justice 5 (2):421-40.

Bernhard, William, J. Lawrence Broz, and William Roberts Clark. 2002. The Political Economy of Monetary Institutions. International Organization 56 (4):693-723.

Bloxham, Donald. 2006. Beyond 'Realism' and Legalism: A Historical Perspective on the Limits of International Humanitarian Law. European Review 14 (4):457-70.

Bradley, Curt, and Judith Kelley. 2008. The Concept of International Delegation. Law and Contemporary Problems 71 (1):1-36.

Burke-White, William W. 2008. Proactive Complementarity: The International Criminal Court and National Courts in the Rome System of Justice. Harvard International Law Journal 49 (1):53-108.

76. The results for common law legal systems here are consistent with the findings in Simmons 2009. See also Powell and Mitchell 2008.

77. See Fortna 2003; and Martin 2005.

78. See Burke-White 2008; and Slaughter and Burke-White 2006, 339-431. 
Carr, Caleb. 2003. The Lessons of Terror: A History of Warfare Against Civilians. New York: Random House.

Danner, Allison Marston. 2003. Enhancing the Legitimacy and Accountability of Prosecutorial Discretion at the International Criminal Court. American Journal of International Law 97 (3):510-52.

. 2006. When Courts Make Law: How the International Criminal Tribunals Recast the Laws of War. Vanderbilt Law Review 59 (1):1-66.

Danner, Allison, and Beth A. Simmons. 2006. Why States Join the International Criminal Court. Manuscript. Available at 〈http://www.law.northwestern.edu/colloquium/international/Danner.pdf $\rangle$. Accessed 8 January 2010.

Dixon, William J. 1994. Democracy and the Peaceful Settlement of International Conflict. American Political Science Review 88 (1):14-32.

Easterly, William, Roberta Gatti, and Sergio Kurlat. 2006. Development, Democracy and Mass Killings. Working Paper \#93. Washington, D.C.: Center for Global Development.

Elkins, Zachary, Andrew T. Guzman, and Beth A. Simmons. 2006. Competing for Capital: The Diffusion of Bilateral Investment Treaties, 1960-2000. International Organization 60 (4):811-46.

Elster, Jon. 1979. Ulysses and the Sirens: Studies in Rationality and Irrationality. Cambridge: Cambridge University Press.

Farer, Tom J. 2000. Restraining the Barbarians: Can International Criminal Law Help? Human Rights Quarterly 22 (1):90-117.

Fearon, James D. 1997. Signaling Foreign Policy Interests: Tying Hands Versus Sinking Costs. Journal of Conflict Resolution 41 (1):68-90.

Fehl, Caroline. 2004. Explaining the International Criminal Court: A 'Practice Test' for Rationalist and Constructivist Approaches. European Journal of International Relations 10 (3):357-94.

Fortna, Virginia Page. 2003. Scraps of Paper? Agreements and the Durability of Peace. International Organization 57 (2):337-72.

Gilligan, Michael J. 2006. Is Enforcement Necessary for Effectiveness? A Model of the International Criminal Regime. International Organization 60 (4):935-67.

Glasius, Marlies. 2006. The International Criminal Court: A Global Civil Society Achievement. London: Routledge.

Goldsmith, Jack L. 2003. The Self-Defeating International Criminal Court. Chicago Law Review 70 (1):89-104.

Goldsmith, Jack L., and Eric A. Posner. 2005. The Limits of International Law. New York: Oxford University Press.

Ho, Daniel E. 2002. Compliance and International Soft Law: Why Do Countries Implement the Basle Accord? Journal of International Economic Law 5 (3):647-88.

Holmes, Stephen. 1988. Precommitment and the Paradox of Democracy. In Constitutionalism and Democracy, edited by Jon Elster and Rune Slagstad, 195-240. Cambridge: Cambridge University Press.

Humphreys, Macartan, and Jeremy M. Weinstein. 2006. Handling and Manhandling Civilians in Civil War. American Political Science Review 100 (3):429-47.

Katzenstein, Suzanne. 2009. Strategic Delegation and the Establishment of the International Criminal Court. Paper presented at the 67th Annual Meeting of the Midwest Political Science Association, April, Chicago.

Keohane, Robert O., Andrew Moravcsik, and Anne-Marie Slaughter. 2000. Legalized Dispute Resolution: Interstate and Transnational. International Organization 54 (3):457-88.

Kiss, Elizabeth. 2000. Moral Ambition Within and Beyond Political Constraints: Reflections on Restorative Justice. In Truth V. Justice: The Morality of Truth Commissions, edited by Robert I. Rotberg and Dennis Thompson, 68-98. Princeton, N.J.: Princeton University Press.

$\mathrm{Ku}$, Julian, and Jide Nzelibe. 2006. Do International Criminal Tribunals Deter or Exacerbate Humanitarian Atrocities? Washington University Law Quarterly 84 (4):777-833.

Lee, Roy S. K. 1999. Introduction: The Rome Conference and Its Contribution to International Law. In The International Criminal Court: The Making of the Rome Statute-Issues, Negotiations, and Results, edited by Roy S. Lee, 1-39. The Hague, Netherlands: Kluwer Law International. 
Maoz, Zeev, and Dan S. Felsenthal. 1987. Self-Binding Commitments, the Inducement of Trust, Social Choice, and the Theory of International Cooperation. International Studies Quarterly 31 (2):177-200. Martin, Lisa L. 2005. The President and International Commitments: Treaties as Signaling Devices. Presidential Studies Quarterly 35 (3):440-65.

Mearsheimer, John J. 2001. The Tragedy of Great Power Politics. New York: Norton.

Mégret, Frédéric. 2005. Why Would States Want to Join the ICC? A Theoretical Exploration Based on the Legal Nature of Complementarity. In Complementary Views on Complementarity, edited by Jann K. Kleffner and Gerben Kor, 1-52. The Hague, Netherlands: T.M.C. Asser Press.

Meierhenrich, Jens, and Keiko Ko. 2009. How Do States Join the International Criminal Court? The Implementation of the Rome Statute in Japan. Journal of International Criminal Justice 7 (2):233-56.

Méndez, Juan E. 2001. National Reconciliation, Transnational Justice, and the International Criminal Court. Ethics and International Affairs 15 (1):25-44.

Meyer, John W., John Boli, George M. Thomas, and Francisco O. Ramirez. 1997. World Society and the Nation-State. American Journal of Sociology 103 (1):144-81.

Moravcsik, Andrew. 2000. The Origins of Human Rights Regimes: Democratic Delegation in Postwar Europe. International Organization 54 (2):217-52.

Neumayer, Eric. 2009. A New Moral Hazard? Military Intervention, Peacekeeping and the International Criminal Court. Journal of Peace Research 46 (5):659-70.

Pace, William R., and Jennifer Schense. 2002. The Role of Non-Governmental Organizations. In The Rome Statute of the International Criminal Court: A Commentary, edited by Antonio Cassese, Paola Gaeta, and John R. W. D. Jones, 105-43. Oxford, England: Oxford University Press.

Peskin, Victor A. 2008. International Justice in Rwanda and the Balkans: Virtual Trials and the Struggle for State Cooperation. New York: Cambridge University Press.

Posen, Barry R. 1993. The Security Dilemma and Ethnic Conflict. Survival 35 (1):27-47.

Powell, Emilia Justyna, and Sara McLaughlin Mitchell. 2008. The Creation and Expansion of the International Criminal Court: A Legal Explanation. Paper presented at the 66th Annual Meeting of the Midwest Political Science Association, April, Chicago.

Ratner, Steven R. 2003. Precommitment Theory and International Law: Starting a Conversation. Texas Law Review 81 (7):2055-81.

Scheffer, David J. 2002. Staying the Course with the International Criminal Court. Cornell International Law Journal 35 (1):47-100.

Schultz, Kenneth A. 2001. Looking for Audience Costs. The Journal of Conflict Resolution 45 (1):32-60.

Simmons, Beth A. 2009. Mobilizing for Human Rights: International Law in Domestic Politics. New York: Cambridge University Press.

Simmons, Beth A., and Lisa Martin. 2002. International Organizations and Institutions. In Handbook of International Relations, edited by Walter Carlsnaes, Thomas Risse, and Beth A. Simmons, 192211. London: Sage Publications.

Slaughter, Anne-Marie, and William Burke-White. 2006. The Future of International Law Is Domestic (or, The European Way of Law). Harvard International Law Journal 47 (2):327-52.

Smith, Heather. 2004. The International Criminal Court and Regional Diffusion. Paper presented at the 5th Pan-European Conference on International Relations, September, The Hague, Netherlands.

Snyder, Jack L., and Leslie Vinjamuri. 2003/2004. Trials and Errors: Principle and Pragmatism in Strategies of International Justice. International Security 28 (3):5-44.

Swaine, Edward T. 2003. Unsigning. Stanford Law Review 55 (5):2061-90.

Tochilovsky, Vladimir. 2003. Globalizing Criminal Justice: Challenges for the International Criminal Court. Global Governance 9 (3):291-99.

Valentino, Benjamin, Paul Huth, and Dylan Balch-Lindsay. 2004. 'Draining the Sea': Mass Killing and Guerrilla Warfare. International Organization 58 (2):375-407.

Valentino, Benjamin, Paul Huth, and Sarah Croco. 2006. Covenants Without the Sword: International Law and the Protection of Civilians in Times of War. World Politics 58 (3):339-77.

Wagner, R. Harrison. 2000. Bargaining and War. American Journal of Political Science 44 (3):469-84.

Walter, Barbara F 1999. Designing Transitions from Civil War: Demobilization, Democratization, and Commitments to Peace. International Security 24 (1):127-55. 
Copyright of International Organization is the property of Cambridge University Press and its content may not be copied or emailed to multiple sites or posted to a listserv without the copyright holder's express written permission. However, users may print, download, or email articles for individual use. 